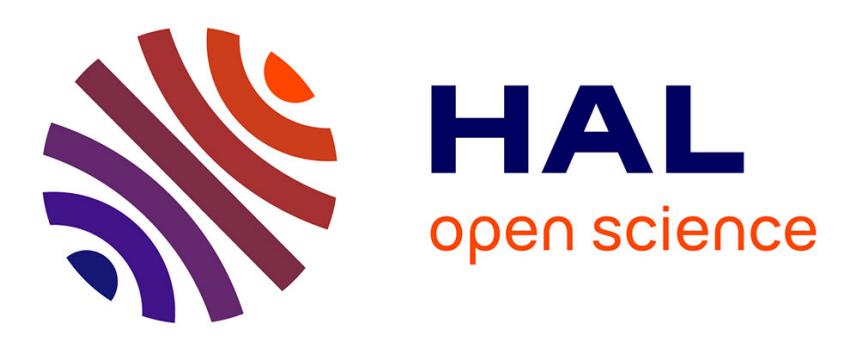

\title{
Depositional model and stratigraphic architecture of rift climax Gilbert-type fan deltas (Gulf of Corinth, Greece)
}

Sébastien Rohais, R. Eschard, François Guillocheau

\section{To cite this version:}

Sébastien Rohais, R. Eschard, François Guillocheau. Depositional model and stratigraphic architecture of rift climax Gilbert-type fan deltas (Gulf of Corinth, Greece). Sedimentary Geology, 2008, 210 (3-4), pp.132-145. 10.1016/j.sedgeo.2008.08.001 . insu-00348005

\section{HAL Id: insu-00348005 https://hal-insu.archives-ouvertes.fr/insu-00348005}

Submitted on 9 Jan 2009

HAL is a multi-disciplinary open access archive for the deposit and dissemination of scientific research documents, whether they are published or not. The documents may come from teaching and research institutions in France or abroad, or from public or private research centers.
L'archive ouverte pluridisciplinaire HAL, est destinée au dépôt et à la diffusion de documents scientifiques de niveau recherche, publiés ou non, émanant des établissements d'enseignement et de recherche français ou étrangers, des laboratoires publics ou privés. 
Depositional model and stratigraphic architecture of rift climax Gilbert-type fan deltas (Gulf of Corinth, Greece)

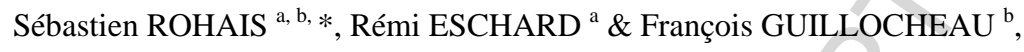 \\ ${ }^{a}$ IFP, Division Géologie - Géochimie - Géophysique, 1-4 avenue de Bois Préau, 92582, Rueil- \\ Malmaison, France \\ b Géosciences-Rennes, UMR 6118, Université de Rennes 1, Campus de Beaulieu, 35042, Rennes Cedex
}

* Corresponding author.

E-mail address: sebastien.rohais@ifp.fr (S. Rohais).

\title{
Abstract
}

Facies, depositional model and stratigraphic architecture of Pleistocene giant Gilbert-type fan deltas are presented, based on outcrop data from the Derveni-Akrata region along the southern coast of the Gulf of Corinth, Greece. The common tripartite consisting of topset, foreset and bottomset (Gilbert, 1885) has been identified, as well as the most distal environment consisting of turbidites, and is organised in a repetitive pattern of four main systems tracts showing a clear facies and volumetric partitioning.

The first systems tract (ST1) is characterised by the lack of topset beds and the development of a by-pass surface instead, thick foresets and bottomset beds, and thick well-developed turbiditic systems. This systems tract (ST1) is organised in an overall progradational pattern. The second systems tract (ST2) is characterised by a thin topset and almost no foreset equivalent. This systems tract is not always wellpreserved and is organised in an overall retrograding trend with a landward shift in the position of the offlap break. The offshore is characterised by massive sandy turbidites. The third systems tract (ST3) is characterised by small scale deltas prograding above the staked topsets of the giant Gilbert-type fan delta. Those small Gilbert-type fan deltas are generally organised in a pure progradation evolving to an aggradational-progradational pattern. In the distal setting of those small Gilbert-type fan deltas, almost no deposits are preserved on the remaining topography of the previous Gilbert-type fan delta. The fourth systems tract (ST4) is characterised by continuous vertically aggrading topsets that laterally pass into aggrading and prograding foresets. Bottomsets and distal turbiditic systems are starved. This fourth systems tract (ST4) is organised in an overall aggrading trend. 
These giant Gilbert-type fan deltas correspond to the Middle Group of the Corinth Rift infill and their stratigraphic development was strongly influenced by evolving rift structure. They record the migration of the depocenter from the rift shoulder to the rift axis in four main sequences from ca. 1.5 to $0.7 \mathrm{Ma}$, related to the migration of fault activity. It is worth noting that the maximum paleobathymetry was recorded during the final stage of the progradation of the Middle Group, suggesting that the rift climax was diachronous at the scale of the entire basin. The rapid ( $<1 \mathrm{Ma})$ structural and sedimentological evolution, the migration of fault activity as well as the youth of the Corinth Rift, are probably exceptional factors allowing the characterisation of such diachronism.

Keywords: Gilbert-type fan delta, Corinth Rift, Climate, Sediment Supply, Pleistocene

\section{Introduction}

Gilbert-type fan deltas are commonly described from tectonically active settings (e.g. Gawthorpe and Colella, 1990; Dart et al., 1994; Dorser et al., 1995) and the topset to foreset transition is often used for qualifying the interaction of variation in accommodation (A) and sediment supply (S) (e.g. Gawthorpe et al., 1994; Garcia-Garcia et al., 2006). Stratigraphic architectures of Gilbert-type fan deltas have thus been widely studied following the work of Gilbert (1885), especially the topset to foreset transition (e.g. Gawthorpe and Colella, 1990; Doutsos and Poulimenos, 1992; Dart et al., 1994). However, we still lack a complete depositional model, from the most proximal alluvial setting to the distal offshore, establishing the relationship between facies distribution and stratigraphic architecture. Moreover, the overall evolution from occurrence, growth to decay of a Gilbert-type fan deltas system has never been proposed from a rift basin. These two main questions: What is the facies to stratigraphic architecture relationship in a Gilberttype fan delta? and How a Gilbert-type fan deltas system evolve through time in a rift basin? are addressed in this paper based on the analysis of facies, facies associations, stratigraphical correlations using physical tracing, field mapping, sequence stratigraphy and biostratigraphy.

The present study is based on the Gulf of Corinth because the whole southern margin of the Gulf of Corinth was fully exhumed during recent Quaternary uplift, providing continuous outcrops showing the margin organisation from the rift shoulder to the main graben axis. The stratigraphic architecture of the Gilbert-type fan deltas was then restored at both the margin scale (ca. $25 \mathrm{~km}$ ) and fine-scale (ca. 0.01 to 1 
$\mathrm{km}$ ) in the central part of the southern coast of the Gulf of Corinth, to provide a complete depositional model for the Gilbert-type fan delta and to characterise their evolution through time and space in a rift.

\section{Regional setting}

\subsection{Tectonics}

The Gulf of Corinth is one of the most recent extensional features in the Aegean area. It is a $105 \mathrm{~km}$ long and $30 \mathrm{~km}$ wide ESE-WNW-trending graben that separates the Peloponnesus from continental Greece (Fig. 1). Extension in the Gulf of Corinth is assumed to have started during the Pliocene and still continues today (e.g. Briole et al., 2000). The present-day Gulf is bounded on each side by recent active normal faults (e.g. Jackson et al., 1982; Roberts et al., 1993; Moretti et al., 2003). WNW-trending normal faults with a vertical displacement of up to 3,000 $\mathrm{m}$ subdivide the southern coast in a series of tilted blocks (5 to 8 km-wide and 5 to 10 km-long) (e.g. Doutsos and Poulimenos, 1992; Roberts et al., 1993; Koukouvelas et al., 1999). The southernmost block of the studied area is bounded by the Killini Fault, a major north dipping fault segment (Fig. 1c). The Killini block is tilted to the south by up to $25-30^{\circ}$, similarly to most of the fault blocks. The second main block to the north is the Mavro block (Fig. 1). The third block corresponds to the Valimi-Xylokastro block. This third block is bounded to the north by a series of north dipping faults as the Akrata Fault (Fig. 1). This fault bounds the last and fourth block cropping out in the study area, the Akrata block.

\subsection{Stratigraphy}

The gross tectonostratigraphic architecture (Fig. 1) of the southern margin of the Gulf of Corinth was described by Rohais et al. (2007a), and the age and paleoenvironmental evolution by Rohais et al. (2007b). These regional studies provide a structural and stratigraphic framework for the detailed sedimentological study presented here.

The syn-rift fill of the southern coast of the Gulf of Corinth is subdivided into three main lithostratigraphic units (Fig. 2; Rohais et al., 2007a): (1) a Lower Group consisting of fluvio-lacustrine deposits, (2) a Middle Group consisting of thick Gilbert-type fan delta conglomerates and (3) an Upper Group including slope deposits, Gilbert-type fan deltas and stepped uplifted terraces along the coastline (Fig. 1). 
Age determination of the Lower Group is difficult because of the lack of diagnostic stratigraphic markers. Ages ranging from Miocene to Lower Pleistocene have been previously proposed (e.g. Sauvage, 1977; Danatsas, 1989, 1994; Muntzos, 1992). More recent palynological data from the study area suggests a Lower Pleistocene age (Rohais et al., 2007b; Ford et al., in press), while the lowermost syn-rift deposits of the Lower Group are attributed to the Upper Pliocene (e.g. Rohais et al., 2007b).

The age of the Middle Group sediments is also controversial, estimates ranging from Calabrian $(\sim 1.8$ to $0.8 \mathrm{Ma}$ ) to Middle Pleistocene (Dercourt, 1964; Symeonidis et al., 1987; Malartre et al., 2004). Recent palynological analysis have provided ages ranging from 1.5 and 1.1 Ma to slightly younger than $0.7 \mathrm{Ma}$ (Rohais et al., 2007b; Ford et al., in press).

Ages for the Upper Group based on radiogenic isotopic methods and nannofossils, range from 0.386 Ma to 305 years BC (e.g. Keraudren and Sorel, 1987; Stiros and Pirazzoli, 1998; McNeill and Collier, 2004). The age model used in this paper is based on the most recent work (Rohais et al., 2007b; Ford et al., in press) and on the well-constrained ages from the Upper Group. Accordingly, the lowermost part of the Lower Group is Upper Pliocene ( 2.6 to $3.6 \mathrm{Ma}$ ), the transition from the Lower Group to the Middle Group occurred around 1.5 Ma, and the transition from the Middle Group to the Upper Group around 0.7 Ma (Fig. 2).

\section{Sedimentology and facies analysis}

Detailed sedimentological studies of the southern margin of the Corinth Rift have been previously published, especially for the giant Gilbert-type fan deltas which are well exposed along the margin (e.g. Ori et al., 1991; Poulimenos et al., 1993; Dart et al., 1994; Zelilidis, 2003). Nevertheless, these studies have never been integrated into an overall stratigraphic architecture from the rift margin to the distal graben axis (Middle Group), nor have they established a complete depositional model for the Gilbert-type fan deltas at very fine-scale. Here, we present a description of the main facies (Table 1, Fig. 3) for the Gilbert-type fan deltas cropping out along the southern coast of the Gulf of Corinth in the Derveni-Akrata region (Fig. 1). Each facies has been described, interpreted and classified from the coarsest (G) to the finest (F) (Table 1). Facies have then been grouped in facies associations to document the main depositional setting. Four main facies associations have been identified with the common tripartite of the 
Gilbert-type fan delta (Topset: GDT, Foreset: GDF and Bottomset: GDB) and the distal facies (Basin and Turbidite: BT).

\subsection{Facies association GDT: giant Gilbert-type Delta Topset}

Description: The giant Gilbert-type Delta Topset (GDT) facies association consists of poorly sorted granule to cobble conglomerate (G1, G2, G3, G4 in Table 1) organised in tabular packages (Fig. 3b) with great lateral extent (0.1 to 5 m-thick, 100 to 1000 m-long). The most proximal facies (G1) corresponds to angular poorly sorted conglomerate with scattered boulder (Fig. 3a). Massive beds are poorly structured (Fig. 3c). Thinner beds show erosional bases, pebble imbrication and trough cross-bedding. Crossstratified sandstones (S1) laterally grade into well-bedded mudstone (F3) and reddish claystone (F7) with rootlets and carbonate concretions. This facies association is characterised by conglomeratic facies organised in fining-upward sequences of 5 to 40 -m thick (Fig. 4a). Fine-grained facies and limestones (Fig. 5) locally occur (F6, L1, L2 in Table 1). Facies L1 (Fig. 3h) contains red algal, blue algal and green algal with marine affinity. Facies L2 contains freshwater ostracods and gastropods (Rohais et al., 2007b). Conglomerate is found in very well sorted clast-supported granule to pebble conglomerate close to the lateral transition into the giant Gilbert-type Delta Foreset (GDF) facies association.

Interpretation: Erosional basal surfaces, trough cross-bedding, grain-size sorting and fining-upward trends (G3, G4, S1) indicate stream and broad channelised flow transport (e.g. Miall, 1977; Nemec and Steel, 1984). Massive sheets of conglomerate (G2) suggest less confined flows and sheet flood events. Finer grained facies (S1, F3) are interpreted to have been deposited in overbank/subordinate channel environments. Red soil also occurred (F7) indicating prolonged periods of non-deposition laterally to the fluvial channels. Texture and geometry of this facies association are consistent with braidplain deposits made up of floodplain fines and coarse-grained deposits of high-discharge bedload (active channel width: $20 \mathrm{~m}$ to $2 \mathrm{~km}$ ). Interbedded facies interpreted as products of lagoons and restricted basins with marine (F6, L1) or lacustrine faunas (L2) indicate that the fan delta prograded into either marine or lacustrine water bodies.

\subsection{Facies association GDF: giant Gilbert-type Delta Foreset}


Description: The giant Gilbert-type Delta Foreset (GDF) (Fig. 4b) facies association consists of sandstones to pebble conglomerates organised in tabular to lenticular, 25 to $35^{\circ}$ dipping beds $(0.2$ to 5 mthick, 50 to 900 m-long). Clasts are generally sub-rounded to rounded, and pebbles are in many places imbricated. Inverse- and normal-grading, as well as clast-supported openwork texture are common. The strata display slightly erosional bases. The foreset angles diminish downdip to merge with the horizontal finer-grained bottomsets (Gilbert-type Delta Bottomset, GDB, Fig. 6). Units of this facies association are organised in 5 to 50 m-thick packages (Fig. 4b) generally beginning with crudely stratified amalgamated and massive beds (G5 in Table 1) above erosional bases cutting across finer deposits (Fig. 3d) and passing upward into well-structured sheets of conglomerates and sandstones (G6, S3 in Table 1). Foreset strata are commonly organised in a radial to conical pattern in plan view, representing a fan delta shape (Fig. 1).

Interpretation: Matrix-rich foreset deposits are interpreted as the result of cohesive and non-cohesive mass flows (e.g. Lowe, 1982; Collela et al., 1987; Prior and Bornhold, 1988). Matrix-poor foreset conglomerates are interpreted as the results of avalanche grainflow on a steep slope (e.g. Collela et al., 1987). Finer-grained facies may correspond to episodes of low sediment discharge and/or alluvial sediment storage. Conglomeratic facies correspond to high-discharge flood events from either alluvial fan debris flow, topset braided rivers, or both. Massive conglomerate beds are interpreted as arising from catastrophic events occurring after a period of relatively low sediment discharge. Some scours on the upper parts of the foreset slope suggest gravity instabilities and slope failure in relation to high-discharge events or sediment accumulation along the delta shoreline exceeding the angle of repose (e.g. Dart et al., 1994).

\subsection{Facies association GDB: giant Gilbert-type Delta Bottomset}

Description: The giant Gilbert-type Delta Bottomset (GDB) facies association (Fig. 4c) consists of granule to pebble conglomerate (G7, G8 in Table 1) organised in tabular to lenticular, gently dipping to horizontal beds $\left(0.2\right.$ to 5 m-thick, dip $<10^{\circ}$ ) (Fig. 3e), interbedded with laminated pebbly sandstone, sandstone or siltstone beds (F1, F2, F4, S6 in Table 1). Conglomerate beds show basal and upper erosional surfaces. Pebbles are commonly imbricated or organised in tabular cross-stratification. Floating pebbles within and at the top of beds are abundant. Inverse- and normal-grading developed above slightly 
erosional bases are also common. Clasts are generally sub-rounded to rounded. Cross- to parallellaminated claystones to siltstones with current-ripples form large-scale undulating beds (Fig. 3e; 5-30 mbroad). Chaotic deposits, muddy matrix-rich conglomerates and folded deposits (G9, G10 in Table 1) also occur in this facies association (Fig. 3f). This facies association is generally organised in a coarseningupward trend followed by a fining-upward, developed above a slightly erosional surface. Soft-sediment deformation (dewatering structures, contorted bedding, inverse-faults) are common in fine-grained facies below the basal erosional surface.

Interpretation: Beds and grain-size suggest a steep slope feeding these deposits. Floating pebbles, clast imbrication, tabular cross-bedding, erosional surfaces and fine lamination indicate transport processes from cohesive matrix-supported mass flow to low-density turbidite current and fallout deposits (e.g. Lowe, 1982; Nemec and Steel, 1984; Pickering et al., 1986; Collela et al., 1987; Prior and Bornhold, 1988). Facies G8, F1 and F2 suggest by-pass and high-energy currents whereas facies G7 and S6 suggest rapid deposition and freezing from matrix-rich, high-density turbidity currents. Soft-sediment deformation is interpreted as the result of a rapid coarse-grained gravity flow deposition upon finegrained deposits.

\subsection{Facies association BT: Basin offshore and associated Turbidite deposits}

Description: The Basin offshore and Turbidite deposits (BT) facies association (Fig. 4c) consists of finegrained deposits (marl, siltstone, fine sandstone) to pebble conglomerates organised in tabular to lenticular horizontal beds (0.02 to 2 m-thick) (Fig. 3g). This facies association covers a wide range of facies from massive bioturbated white marls (F4) and thinly laminated fine-grained deposits with currentripples (F1), to coarse-grained sandstones with normal grading (S3, S4 in Table 1) and channelised conglomerates with a sharp and deep erosional base. This facies association shows a fining-upward trend. Lateral transitions to facies association of giant Gilbert-type Delta Bottomset (GDB) are characterised by occurrences of facies S6, F1, F2. Fine-grained facies F4 and F5 (Table 1) contain fresh to brackish ostracods and few marine foraminifera (Rohais et al., 2007b).

Interpretation: Inferred sedimentary processes cover a wide range including mass flow, high-density to low-density turbidity currents and deposition fallout (e.g. Bouma, 1962; Lowe, 1982; Nemec and Steel, 1984; Pickering et al., 1986). Channelised conglomerate facies are interpreted as the infill of turbidite 
channels and gullies. Coarse-grained facies (S3, S4) are interpreted as deposits of high-density turbidity currents that by-passed the foreset to bottomset area or resulting from gravity flows that deposited their gravel to pebble fraction up-dip. Finer-grained facies are interpreted as deposits of low-density turbidity currents and suspension fallout. Water depths estimated on the basis of foreset geometry range from 50 to $500 \mathrm{~m}$.

\section{Depositional model}

The subaerial lobe of the Gilbert-type fan delta ranges from 2 to $6 \mathrm{~km}$ in diameter (Fig. 1). Ori et al. (1991) and Dart et al. (1994) previously described the stratigraphic architecture of some of the giant Gilbert-type fan deltas, especially the topset to foreset transition. We have extended these descriptions from the topset to the distal turbidite based on measured sections and panorama interpretations of the Evrostini and the Ilias fan deltas (Fig. 5, 6 and 7). The Evrostini cliff (Fig. 5) shows the lateral transition from proximal facies (GDT) through intermediate facies (GDF, GDB) to distal facies (BT) in less than 5 km, with foreset geometry indicating a bathymetry of $500 \mathrm{~m}$ deep. Four main systems tracts have been identified based on their facies, internal geometry and the relation with their bounding surfaces (Fig. 8).

\subsection{Pure prograding systems tracts (ST1)}

This first systems tract (ST1) is well exposed in the Evrostini cliff at large scale (Fig. 7) as well as finer scale (Fig. 5), and in the Ilias cliff (Fig. 6). As no outcrop exposes both panorama and good accessibility to study this systems tract from topset to turbidite, we combined observation from the Evrostini and Ilias cliffs. The overall progradational pattern and the most massive and coarsest deposits of the giant Gilberttype Delta Foreset (GDF) and Bottomset (GDB) facies associations (e.g. between line 5 and 6, log a. in Fig. 6) have been used as criterion to gather observation from topset to foreset setting with foreset to bottomset and turbidite setting.

The first systems tract (ST1) is characterised by the lack of topset beds and the presence of a by-pass surface instead (e.g. line 5, 9 in Fig. 5). Thick foreset and bottomset beds, and thick heterolithic turbidites occur (e.g. between line 5 and 6 in Fig. 6). The basal surface of the systems tract is erosional in the topset area (unconformity) and laterally passes to a downlap/truncation surface in the bottomset area (line 5 and 10 in Fig. 6). The upper surface in the foreset area shows toplap geometry (e.g. line 5 in Fig. 5). This first 
systems tract (ST1 in Fig. 8e) corresponds to a regime of bypass and erosion of the topset, and to rapid progradation of the Gilbert-type fan delta $(\mathrm{A} / \mathrm{S}<0)$.

\subsection{Retrograding systems tracts (ST2)}

The second systems tract (ST2) is characterised by a thin topset and almost no foreset equivalent (between line 2 and 3 in Fig. 5). Reworked conglomerates and coastal limestones (L1) are generally preserved in the distal topset setting (Fig. 5). As no outcrop exposes both panorama and good accessibility to study this systems tract from topset to turbidite, we combined observation from the Evrostini and Ilias cliffs (Fig. 5 and 6). We used the lack of foreset as a criterion to gather information from the most proximal topset setting to the distal turbidite setting. The offshore deposits are characterised by massive sandy turbidites (Fig. 6). These massive sandy turbidites are organised in a fining-upward trend (log d. in Fig. 6) and recorded an overall landward shift. The basal surface of systems tract (ST2) is a purely erosional surface in the topset to foreset transition of the previous systems tract, and passes laterally into an onlap surface onto previous foreset beds (e.g. line 3 and 6 in Fig. 6). This systems tract (ST1 in Fig. 8d) is not always well-preserved in the topset setting (Fig. 5) and is organised in an overall retrograding trend with a landward shift in the position of the offlap break (A/S > 1).

\subsection{Prograding-aggrading systems tracts (ST3)}

The third systems tract (ST3) is characterised by small-scale deltas prograding over the stacked topsets of the giant Gilbert-type fan delta (Fig. 5). The lateral transition from topset to bottomset within these smallscale Gilbert-type fan deltas is clearly shown, especially between line 3 and 6 on Figure 5 . These small Gilbert-type fan deltas are generally purely prograding to aggrading-prograding. Almost no deposits are preserved on the remaining topography of the previous Gilbert-type fan delta (topset to foreset transition) where by-pass of turbidity currents occurred (Fig. 5 and 6). The offshore deposits are characterised by thinly bedded and fine-grained sandy turbidites, but it still unclear whether the massive sandy turbidite are also distal equivalent of this systems tract or not (between line 3 and 4 in Fig. 6). The basal surface is a composite downlap/truncation in the giant Gilbert-type fan delta topset that passes laterally into a purely erosional surface in the topset to foreset transition of the previous systems tract (e.g. line 3 in Fig. 6). This 
third systems tract (ST3 in Fig. 8c) corresponds to a regime of rapid progradation (A/S 0) followed by a regime of aggradation to progradation $(1>\mathrm{A} / \mathrm{S}>0)$.

\subsection{Aggrading-prograding systems tracts (ST4)}

The fourth systems tract (ST4) is characterised by continuous vertically aggrading topsets that laterally pass into aggrading and prograding foresets (e.g. between line 7 and 8 in Fig. 5 and Fig. 7). Bottomsets and distal turbidite systems were poorly developed during this stage (Fig. 6). This systems tract contains the most massive and coarsest deposits of the giant Gilbert-type Delta Topset (GDT) and Foreset (GDF) facies associations (e.g. between line 7 and 8 in Fig. 5). The basal surface is generally planar and smooth, or erosional in the topset, and laterally passes in the foresets and bottomsets into a downlap surface, locally erosional (e.g. line 2 in Fig. 6). This fourth systems tract (ST4 in Fig. 8b) corresponds to a regime in which sediment supply balanced the accommodation $(\mathrm{A} / \mathrm{S}=1)$ : the deltas were vertically aggrading.

\section{Stratigraphic architecture of the Middle Group}

The overall architecture of the Middle Group can be subdivided into four main sequences (Fig. 9) sensu Mitchum (1977). These four sequences are bounded by relative maximum flooding surfaces (Fig. 9). In the Killini Fan Delta located in the southernmost part of the studied area (Fig. 1), an initial episode of progradation induced a basinward shift of 2 to $4 \mathrm{~km}$ in length of the shoreline into a lacustrine basin 50 to $200 \mathrm{~m}$ deep (Sequence 1). The foreset height progressively increased during the main progradation (mainly ST1 and ST4), and the following transgressive trend is recorded by very thin small scale Gilberttype fan deltas (ST2 and ST3). After a first $3 \mathrm{~km}$ landward advance of the shoreline, a second fan delta system then rapidly prograded 10 to $14 \mathrm{~km}$ northwards into the basin (Sequence 2, Fig. 9). Sequence 2 shows the same overall architecture as Sequence 1 with a major progradation characterised by systems tracts ST1 and ST4 followed by a transgressive trend recorded by systems tracts ST2 and ST3. The Killini Fan Delta (Sequence 1 and 2) progressively onlapped the Alpine basement in the footwall of the border fault (Fig. 9). The onlap indicates sealing of the border fault and a landward shift of fluvial facies toward the rift shoulder while the fan was aggrading (Fig. 9). A planar horizontal surface, perched today at 1500 m altitude, marked the end of the Killini Fan Delta progradation and its abandonment (Fig. 9). This erosional to by-pass surface is similar to the surface occurring upward of a systems tract ST1. 
Then, a basinward shift to the north of around $5 \mathrm{~km}$ of the depocenter and an increase in water depth up to $300 \mathrm{~m}$ was recorded in the basin during deposition of the Mavro and the Ilias fan deltas (Sequence 3). The transgressive trend of Sequence 3 is poorly preserved in the distal setting (Fig. 9). Major faults such as the Mavro Fault were active during deposition of Sequence 3 (Fig. 9). After a 3 km landward advance of the shoreline, the Mavro and Ilias fan deltas were then abandoned and re-incised, feeding Sequence 4 of the Middle Group. This final Sequence 4 corresponded to the Evrostini Fan Delta which recorded the maximum water depth of ca. $500 \mathrm{~m}$. The Evrostini Fan Delta was then abandoned and lies currently at a mean altitude of ca. $1100 \mathrm{~m}$ (Fig. 9).

Based on the conceptual depositional model presented in this paper (Fig. 8), a quantification of the shoreline migration has also been carried out at finer scale. In the Evrostini cliff (Fig. 7), the overall organisation indicates that the shoreline migrated basinward for more than $500 \mathrm{~m}$ in length between the basal ST1 and the thin ST2, and then rapidly migrated landward for about $400 \mathrm{~m}$ during deposition of Sequence 3 (ST3). Then, the shoreline was almost stable during more than $240 \mathrm{~m}$ of sediment deposition (ST4), and finally migrated basinward for more then $500 \mathrm{~m}$ in length (ST1) during Sequence 4. Toward the top of the Evrostini cliff, very fine-scale geometries are well-exposed on the left side of the panorama (Fig. 5). A perched paleo-valley crosscuts these fine-scale geometries in the back-side of the main cliff, detailed in Figure 5. Small-scale (1 to $20 \mathrm{~m}$ high, 5 to $40 \mathrm{~m}$ long) Gilbert-type fan deltas formed part of the giant Gilbert-type fan delta topsets (Fig. 5) and are organised in an overall prograding trend indicating that the shoreline laterally migrated basinward for more than $120 \mathrm{~m}$. Four main landward shifts (amplitude ca. $100 \mathrm{~m}$ in length) are also recorded by thin ST2 within this main progradational trend organised in sequences of 10 to 30 m-thick.

In the Ilias cliff, pure prograding systems tract (ST1) is followed upward by aggrading-prograding systems tract (ST4) and by thick sandy turbidites (ST2) that onlap the previous Gilbert-type fan delta morphology. The systems tracts are stacked in a repetitive pattern showing six 20-100 m-thick sequences within an overall aggrading-prograding trend (Fig. 6), with amplitude of the shoreline trajectory from 50$200 \mathrm{~m}$ in length based on the transition between foreset and bottomset.

\section{Discussion}

\subsection{Control on the Gilbert-type fan delta architecture}


Based on the conceptual depositional model presented in this paper, a quantification of the shoreline migration has been carried out. Two scales of vertical cyclicity at 10's to 100's of meters are recorded within the overall progradation of the Gilbert-type fan delta of the Middle Group (Fig. 5, 6 and 7). The number of cycles (10's to 100's of meters) is higher than the twelve transgressive / regressive cycles documented on the Pleistocene sea level curve of Shackelton et al. (1990) changes during the deposition of the Middle Group (ca. 1.5 to 0.7 Ma; Fig. 2), indicating other controls such as sediment supply or tectonic changes.

Massive sandy turbidites clearly onlap pure prograding systems tract (ST1) and are overlain by late stage prograding-aggrading systems tract (ST3) and aggrading-prograding systems tract (ST4) as proved by downlap surfaces (Fig. 6). Nevertheless, we did not find any evidences as to whether they are contemporaneous to the first stage of the retrograding systems tract (ST2), to the entire deposition of the ST2, or even to a part of the prograding-aggrading systems tract (ST3). As they record a drastic change in the dynamic of the distal setting of the Gilbert-type fan delta, we propose that they are contemporaneous with the retrograding systems tract (ST2) during which topsets are flooded and coarser deposits are stored in the very proximal setting, which is in accordance with onlap geometry and fining-upward trend of these massive turbidites.

\subsection{Control on the Middle Group stratigraphic architecture}

The southern margin of the Gulf shares the same overall stratigraphy (Rohais et al., 2007a) as many nonmarine rift basins, and which is commonly related to the structural evolution of the rift (e.g. Lambiase, 1991). The Lower Group (Fig. 2) recorded the initial stage of rift opening and the progressive flooding of continental to lacustrine environments. Secondly, the Lower Group to Middle Group transition records the deepening-upward lacustrine succession (Fig. 2), that corresponds to the first occurrence of the giant Gilbert-type fan deltas in the Gulf of Corinth. This transition has been already interpreted as a major tectonic event corresponding to a redefinition of the entire structural pattern of the rift (Ori, 1989) and could have corresponded to the Rift Initiation to Rift Climax transition identified in many rift systems (e.g. Prosser, 1993; Lambiase and Bosworth, 1995). The giant Gilbert-type fan deltas of the Middle Group then corresponded to the third member (e.g. Lambiase, 1991) of the rift stratigraphy characterised by a coarsening upward trend and a major progradation. 
While this syn-rift fill is comparable to many other rift basin fills, it is nevertheless remarkable that the Corinth Rift is still active, with a rapidly subsiding 800 m-deep basin. This study shows that the maximum bathymetry increased through time and space, from ca. 200m in the Killini block, to ca. $300 \mathrm{~m}$ in the Mavro block and finally ca. $500 \mathrm{~m}$ in the Evrostini block. While the Rift Climax corresponds to a maximum of water depth in the rift basin, it suggests that the Rift Climax was diachronous in the Gulf of Corinth which is not common in classical rift model. This distinction is probably related to the northward migration of the fault activity during the deposition of the Middle Group. Such diachonism from tiltedblock to tilted-block is not documented in other rift basins, probably due to the rapidity ( $<1 \mathrm{Ma})$ of the phenomena combined with the erosion of its record during a later uplift of the margin.

Within each block, the progradation of the Middle Group is interrupted by a maximum flooding surface recorded by a major landward shift of the shoreline (e.g. between sequence 1 and 2 in the Killini block). It suggests that the A/S ratio is not linear through this time scale and records major changes. Accommodation (A) corresponds to available space resulting from tectonic subsidence and eustasy. While the Middle Group records the evolution from the Rift Climax to the abandonment of the faults along the southern margin of the Corinth Rift, the fault activity would thus be characterised by a progressive decrease of the throw rate until a complete decay occurred. Tectonics would thus not be inferred in such increase in accommodation. This relative increase in accommodation could thus be inferred to eustasy.

Another origin of these landward shifts could alternatively be an increase and decrease of sediment supply (S). Faults initiate, grow and finally end by a decay that induce an increase in sediment supply in response to the uplift of the footwall (e.g. Cowie et al., 2006). Major increase or decrease of the sediment supply that would have a control on the main landward shift, are thus not related to tectonics, but can be inferred to catchment dynamics or climate changes. The four main sequences of the Middle Group are thus overprinted by eustatic or climatic controls.

\section{Conclusions}

Sedimentological studies, detailed geological mapping and stratigraphic correlation in the central part of the southern coast of the Corinth Rift, provided a complete depositional model and a restored stratigraphic architecture of Pleistocene giant Gilbert-type fan deltas. 
Four main systems tracts showing a clear facies and volumetric partitioning have been identified. The first systems tract (ST1) is characterised by the lack of topset beds, thick foresets and bottomset beds, and thick well-developed turbiditic systems. The second systems tract (ST2) is characterised by a thin topset and almost no foreset equivalent, while offshore is characterised by massive sandy turbidites. Massive sandy turbidite are thus contemporaneous with period of time with increasing accommodation and/or decreasing sediment supply. The third systems tract (ST3) is characterised by small scale deltas prograding above the staked topsets of the giant Gilbert-type fan delta. Almost no deposits are preserved on the remaining topography of the previous Gilbert-type fan delta. The offshore deposits are starved and characterised by thin bedded fine-grained turbidites. The fourth systems tract (ST4) is characterised by continuous vertically aggrading topsets that laterally pass to aggrading and prograding foresets. Bottomsets and distal turbiditic systems are starved.

These giant Gilbert-type fan deltas correspond to the Middle Group of the Corinth Rift infill and their stratigraphic development has recorded the migration of the depocenter from the rift shoulder to the rift axis in four main sequences from ca. 1.5 to $0.7 \mathrm{Ma}$. The maximum in paleobathymetry increased through time and space during the deposition of the Middle Group, probably in relationship with the fault activity migration, suggesting that the rift climax was diachronous at the rift scale. Youth and rapidity of the structural evolution of the Corinth Rift are probably exceptional factors allowing the characterisation of such diachronism.

\section{Acknowledgements}

Financial support during the completion of this work was provided by IFP. We wish to thank M. Ford and I. Moretti for their help and constructive remarks. We would like to thank the Institute of Geology and Mineral Exploration (IGME) for providing the opportunities to access to the studied area. Reviews by R. Gawthorpe, P.L. de Boer and C. Fielding greatly improved the quality of the manuscript. 


\section{References}

Bouma, A.H., 1962. Sedimentology of Some Flysch Deposits. Amsterdam, Elsevier, 166 pp.

Briole, P., Rigo, A., Lyon-Caen, H., Ruegg, J., Papazissi, K., Mistakaki, C., Balodimou, A., Veis, G., Hatzfeld, D., Deschamps A., 2000. Active deformation, of the gulf of Korinthos, Greece: results from repeated GPS surveys between 1990 and 1995. J. Geophys. Res. 105 (11), 25605-25625.

Collela, A., De Boer, P.L., Nio, S.D., 1987. Sedimentology of a marine intermontane Pleistocene Gilberttype Fan-delta complex in the Crati Basin, Calabria, southern Italy. Sedimentology, 34, 721-736.

Cowie, P.A., Attal, M., Tucker, G.E., Whittaker, A.C., Naylor, M., Ganas, A., Roberts, G.P., 2006. Investigating the surface process response to fault interaction and linkage using a numerical modelling approach. Basin Res. 18 (3), 231-266. doi: 10.1111/ j.1365-2117.2006.00298.x

Danatsas, I., 1989. Die känozoischen Ostrakoden des NW- und N-Peloponnes und ihre stratigraphische, paläoökologische und paläogeographische Bedeutung. Inaug. Diss. Münster, 171.

Danatsas, I., 1994. Zur Entwicklung der miozänen-altpleitozänen Ostrakoden-Fauna des KorinthBeckens, Griechenland. Münster. Forsch. Geol. Paläont. 76, 191-200.

Dart, C.J., Collier, R.E.Ll., Gawthorpe, R.L., Keller, J.V.A., Nichols, G., 1994. Sequence stratigraphy of (?) Pliocene-Quaternary synrift, Gilbert-type fan deltas, northern Peloponnesos, Greece. Mar. Petrol. Geol. 11, 545-560.

Dercourt, J., 1964. Contribution à l'étude géologique du secteur du Péloponnèse septentrional. PhD thesis, University of Paris.

Dorsey, R.J., Umhoefer, P.J., Renne, P.R., 1995. Rapid subsidence and stacked Gilbert-type fan deltas, Pliocene Loreto Basin, Baja California Sur, Mexico. Sediment. Geol. 98, 181-204.

Doutsos, T., Poulimenos, G., 1992. Geometry and kinematics of activ faults and their seismotectonic significance in the western Corinth-Patras rift (Greece). J. Struct. Geol. 14 (6), 689-699.

Ford, M., Williams, E.A., Malartre, F., Popescu, S.P., (in press). Stratigraphic architecture, sedimentology and structure of the Vouraikos Gilbert-type fan delta, Gulf of Corinth, Greece. In: Paola C., Nichols G.J., Williams E.A. (Eds.). I.A.S., Special Publication.

Garcia-Garcia, F., Fernandez, J., Viseras, C., Soria, J.M., 2006. Architecture and sedimentary facies evolution in a delta stack controlled by fault growth (Betic, southern Spain, late Tortonian). Sediment. Geol. 185, 79-92.

Gawthorpe, R.L., Colella, A., 1990. Tectonic controls on coarse-grained delta depositional systems in rift basins. In: Colella, A., Prior, D.B. (Eds.), Coarse-grained Deltas, Int. Assoc. Sedim., Spec. Publ., vol. 10, pp. 113-127.

Gawthorpe, R.L., Fraser, A.J., Collier, R.E.Ll., 1994. Sequence stratigraphy in active extensional basins: implication for the interpretation of ancient basin-fills. Mar. Petrol. Geol. 11 (6), 642-658.

Gilbert, G.K., 1885. The topographic features of lake shores: Washington, D.C., Unit. States Geol. Survey, $5^{\text {th }}$ Annual Report, 69-123.

Jackson, J. A., Gagnepain, J., Houseman, G., King, G.C.P., Papadimitriou, P., Soufleris, C., Virieux, J., 1982. Seismicity, normal faulting and the geomorphological development of the Gulf of Corinth (Greece): the Corinth earthquakes of February and March 1981. Earth Planet. Sci. Lett. 57, 377397.

Keraudren, B., Sorel, D., 1987. The terraces of Corinth (Greece): a detailed record of eustatic sea level variations during the last 500000 years. Marine Geology 77 (1-2), 99-107.

Koukouvelas, I. K., Asimakopoulos, M., Doutsos, T., 1999. Fractal characteristics of active normal faults: an example of the eastern Gulf of Corinth, Greece. Tectonophysics 308 (1-2), 263-274.

Lambiase, J.J., Bosworth, W., 1995. Structural controls on sedimentation in continental rifts. In: Lambiase, J.J. (Eds.), Hydrocarbon habitat in rift basins, Geol. Soc. Spec. Publ., vol. 80, pp. 117144.

Lambiase, J.J., 1991. A model for tectonic control of lacustrine stratigraphic sequences in continental rift basins. In: Katz, B.J. (Eds.), Lacustrine basin exploration: case studies and modern analogs, American Association of Petroleum Geologists Memoir 50, pp. 265-286.

Lowe, D.R., 1982. Sediment gravity flows: II. Depositional models with special reference to the deposits of high-density turbidity currents. J. Sediment. Petrol., 52, 279-297.

Malartre, F., Ford, M., Williams, E.A., 2004. Preliminary biostratigraphy and 3D lithostratigraphy of the Vouraikos Gylbert-type fan delta. Implications for the evolution of the Gulf of Corinth, Greece. C. R. Geoscience 336, 269-280.

Miall, A.D., 1977. A review of braided river depositional environments. Earth Sci. Rev., 13, 1-62. 
Mitchum, R.M., 1977. Seismic stratigraphy and global changes of sea level, Part 1: Glossary of terms used in seismic stratigraphy. In: Payton, C.E., (Ed), Seismic Stratigraphy - Applications to Hydrocarbon Exploration, Association of Petroleum Geologists Memoir 26, 205-212.

Muntzos, T., 1992. Palyno- und Paläoklima-Stratigraphie der pliozänen und altpleistozänen Sedimente der nördlichen und nordwestlichen Peloponnes (Hellas). Newsletters on Stratigraphy 27 (1-2), 71-91.

McNeill, L.C., Collier, R.E.Ll., 2004. Footwall uplift rates of the Eastern Eliki fault, Gulf of Corinth, Greece, inferred from Holocene and Pleistocene terraces. J. Geol. Soc. Lond. 161, 81-92.

Moretti, I., Sakellariou, D., Lykousis, V., Micarelli, L., 2003. The Gulf of Corinth: a half graben? Journal of Geodynamics 36, 323-340.

Nemec, W., Steel, R.J., 1984. Alluvial and coastal conglomerates: their significant features and some comments on gravelly mass-flow deposits. In: Koster, E.H., Steel, R.J., (Eds), Sedimentology of Gravels and Conglomerates. Memoir 10, pp. 1-31.

Ori, G. G., 1989. Geological history of the extensional basin of the Gulf of Corinth (?MiocenePleistocene), Greece. Geology 17, 918-921.

Ori, G. G., Roveri, M., Nichols, G., 1991. Architectural patterns in large-scale Gilbert-type delta complexes, Pleistocene, Gulf of Corinth, Greece. In: Miall, A.D., Tyler, N., (Eds), The three dimensional facies architecture if terrigenous clastic sediments and its implications for hydrocarbon discovery and recovery, SEPM, Concept in Sedimentology and Paleontology, pp 207-216.

Pickering, K.T., Stow, D.A.V., Watson, M.P., Hiscott, R.N., 1986. Deep-water facies, processes and models: a review and classification scheme for modern and ancient sediments. Earth Sci. Rev. 23, $75-174$.

Poulimenos, G., Zelilidis, A., Kontopoulos, N., Doutsos, T., 1993. Geometry of trapezoidal fan deltas and their relationship to extensional faulting along the south-western active margins of the Corinth rift, Greece. Basin Res. 5, 179-192.

Prior, D.B., Bornhold, B.D., 1988. Submarine morphology and processes of fyord fan deltas and related high-gradient systems: modern examples from British Columbian. In: W Nemec, RJ Steel (eds) Fan Deltas: Sedimentology and tectonic settings. Blackie, London, pp. 125-143.

Prosser, S., 1993. Rift-related linked depositional systems and their seismic expression. In: Williams, G.D., Dobbs, A. (Eds.), Tectonics and Seismic Sequence Stratigraphy, Spec. Publ. Geol. Soc. Lond. 71, 35-66.

Roberts, G. P., Gawthorpe, R. L., Stewart, I. 1993. Surface faulting within active normal fault-zones: examples from the Gulf of Corinth fault system, central Greece. Zeitschrift für Geomorphologie N. F. suppl. -Bd. 94, 303-328.

Rohais, S., Eschard, R., Ford, M., Guillocheau, F., Moretti, I., 2007a. Stratigraphic architecture of the Plio-Pleistocene Infill of the Corinth rift: implications for its structural evolution. Tectonophysics 440, 5-28.

Rohais, S., Joannin, S., Colin, J.P., Suc, J.P., Guillocheau, F. Eschard, R., 2007b. Age and environmental evolution of the syn-rift fill of the southern coast of the Golf of Corinth (Akrata-Derveni region, Greece). Bull. Soc. Geol. France, t. 178, n³, 231-243.

Sauvage, J., 1977. L'apport de la Palynologie dans la connaissance du Plio-Pléistocène de la région de Corinthe (Grèce): le problème des limites et des corrélations stratigraphiques. C. R. Acad. Sc. Paris 285, série D, 279-282.

Shackleton, N. J., Berger, A., Peltier, W.R., 1990. An alternate astronomical calibration of the lower Pleistocene timescale based on ODP site 677. Trans. R. Soc. Edinburgh Earth Sci. 81, 251-261.

Stiros, S.C., Pirazzoli, P., 1998. Late Quaternary coastal changes in the Gulf of Corinth, Greece: tectonics earthquake, archaeology. Guidebook for the Gulf of Corinth Field Trip, 14-16 September 1998. Patras University, Greece, Patras.

Symeonidis, N., Theothorou, G., Schutt, H., Velitzelos, E., 1987. Paleontological and stratigraphic observations in the area of Achaia and Etoloakarnania W-Greece. Ann. Geol. Pays Hell., Athens, 38, 317-353.

Zelilidis, A., 2003. The geometry of fan-deltas and related turbidites in narrow linear basin. Geol. J. 37, 116. 
Fig. 1.

(A) Location of the study area. (B) Geological map of the central part of the Gulf of Corinth showing the fault pattern and the main lithostratigraphic units. (C) N-S cross-section of the southern coast of the Gulf of Corinth (simplified after Rohais et al., 2007a).

Fig. 2.

Synthetic sedimentary column of the syn-rift fill in the central part of the southern coast of the Gulf of Corinth, simplified after Rohais et al. (2007a). Ages from Rohais et al. (2007b).

Table 1

Main characteristics of the sedimentary facies and their interpretation in terms of depositional process. G: Gravel, S: Sand, F: Fine and L: Limestone.

Fig. 3.

Outcrops showing various sedimentological facies of the Middle Group. (A) Block embedded in matrixsupported conglomerates deposited by debris flow (facies G1). (B) Poorly organized clast-supported conglomerates of facies G2 in an alluvial fan setting. (C) facies G3 and G4 of the giant Gilbert-type Delta Topset facies association (GDT). (D) facies G5 and G6 of giant Gilbert-type Delta Foreset facies association (GDF). (E) Alternation of giant Gilbert-type Delta conglomeratic Bottomset (GDB) with Basin and Turbidite (BT) facies associations with incised channel geometry. (F) Chaotic deposits of facies G9. (G) Detailed view of turbidite deposits in Basin and Turbidite (BT) facies association. (H) Thin section of algal limestone L1. Facies details in Table 1.

Fig. 4.

Measured sections for each facies association of the Middle Group. (A) Section of giant Gilbert-type Delta Topset facies association (GDT). (B) Section of giant Gilbert-type Delta Foreset facies association (GDF). (C) Section of giant Gilbert-type Delta Bottomset (GDB) to Basin and Turbitide (BT) facies associations. Location of sections in Figure 1. 
Fig. 5.

Panorama (A) and interpretation (B: systems tracks, C: facies associations) of the Evrostini Gilbert-type fan delta topsets showing fine-scale geometries within Sequence 4 of the Middle Group. GDT, GDF and GDB refer to facies associations along the depositional profile. Toplap surfaces (3 and 4) and composite toplap-downlap surfaces (1) are shown. Toplap surfaces are associated with by-pass facies (G4, S1), composite toplap-downlap surfaces are associated with the same by-pass facies overlaid by transgressive marine facies (L1). Location in Figure 1.

Fig. 6.

Panorama (A) and interpretation (B: systems tracks, C: facies associations) of a detail of the Ilias Gilberttype Fan Delta (below the Evrostini Fan Delta) at the foreset-bottomset transition (Sequence 3 of the Middle Group). The lateral transition of foreset to bottomset and finally to fine-grained turbidite is clearly shown between surface 5 and 6. Downlap surfaces (e.g. 4), composite downlap-toplap surfaces (e.g. 11, 12) and onlap surfaces (e.g. 3, 7) are shown on the photo. Onlap surfaces are associated with thick fine- to coarse-grained sandy turbidites. Downlap to downlap-toplap surfaces are associated with aggradational and progradational foresets. During the progradation, bottomsets consisting of conglomeratic debris flow were formed while thin sandy turbidites were also deposited basinward. Location in Figure 1.

Fig. 7.

Panorama (A) and interpretation (B) of the Evrostini giant Gilbert-type fan delta. The facies transitions of the Middle Group are shown: the GDT facies association to the left passing laterally to GDF, GDB and BT facies association to the right. The two last sequences ( 3 and 4 ) of the northward progradation of the Middle Group are shown. Sequence 3 is characterised by the lack of topset beds and the development of by-pass surface instead (Toplap surface), and thick foresets and bottomsets (ST1). Very thin retrograding systems tract (ST2) and prograding-aggrading systems tract (ST3) occur on top of the systems tract ST1 of Sequence 3. Stratal pattern of Sequence 4 first shows an aggradational trend (ST4) followed by a progradational to pure progradational trend (ST1). The terraces made of red scree of the Upper Group unconformably overlies the foresets and bottomsets of the Evrostini fan delta, illustrating the major 
relative sea-level drop which occurred after the deposition of the Middle Group. The cliff is about $600 \mathrm{~m}$ high. Location in Figure 1.

Fig. 8.

Schematic illustration of the Gilbert-type stratigraphic architecture and facies relations with regard to the accommodation (A) to sediment supply (S) ratio, based on the Ilias and Evrostini fan deltas. Four main systems tracts can be identified at the giant Gilbert-type fan delta scale: pure prograding systems tract (ST1), retrograding systems tract (ST2), prograding aggrading systems tract (ST3) and aggradingprograding systems tract (ST4). Note that the fine- to coarse-grained sandy turbidites mostly accumulated during the deposition of the retrograding systems tract (ST2).

Fig. 9.

Restored north-south section of the central part of the Corinth margin showing the stratigraphic architecture of the Middle Group and its unconformable relationship with the Upper Group. Three stratigraphic sections are presented for each of the main tilted blocks: (A) Killini, (B) Mavro and (C) Evrostini fan deltas. Numbers refer to the sequence nomenclature used in the text. Age of sample M101 ranges from 1.78 to $0.9 \mathrm{Ma}$. Sample M04 ranges from 0.82 to $0.7 \mathrm{Ma}$. Sample I03 ranges from 0.65 to 0.3 Ma. Ages from Rohais et al. (2007b). Location in Figure 1. 
Figure 1
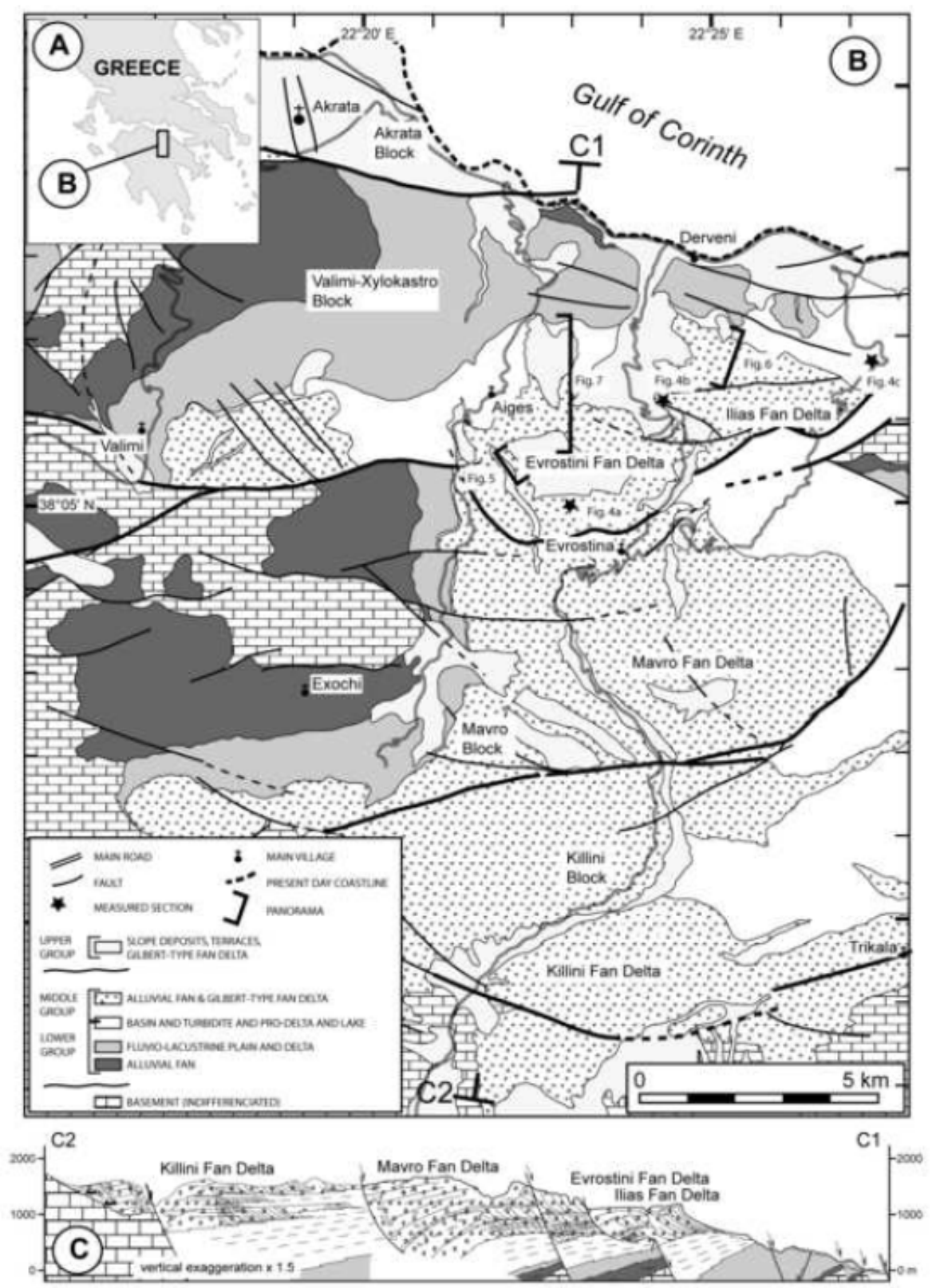
Figure 2

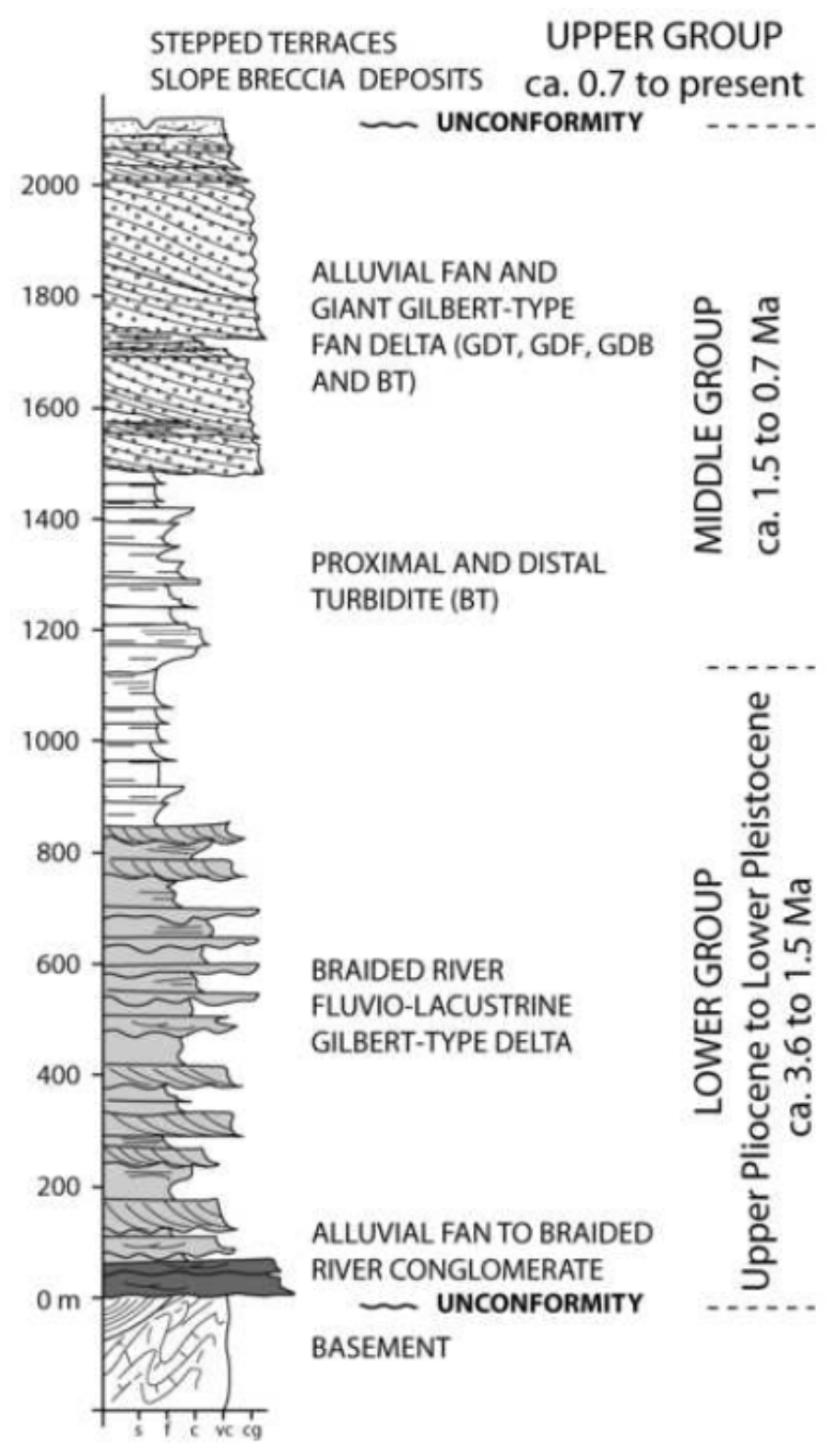


Figure 3
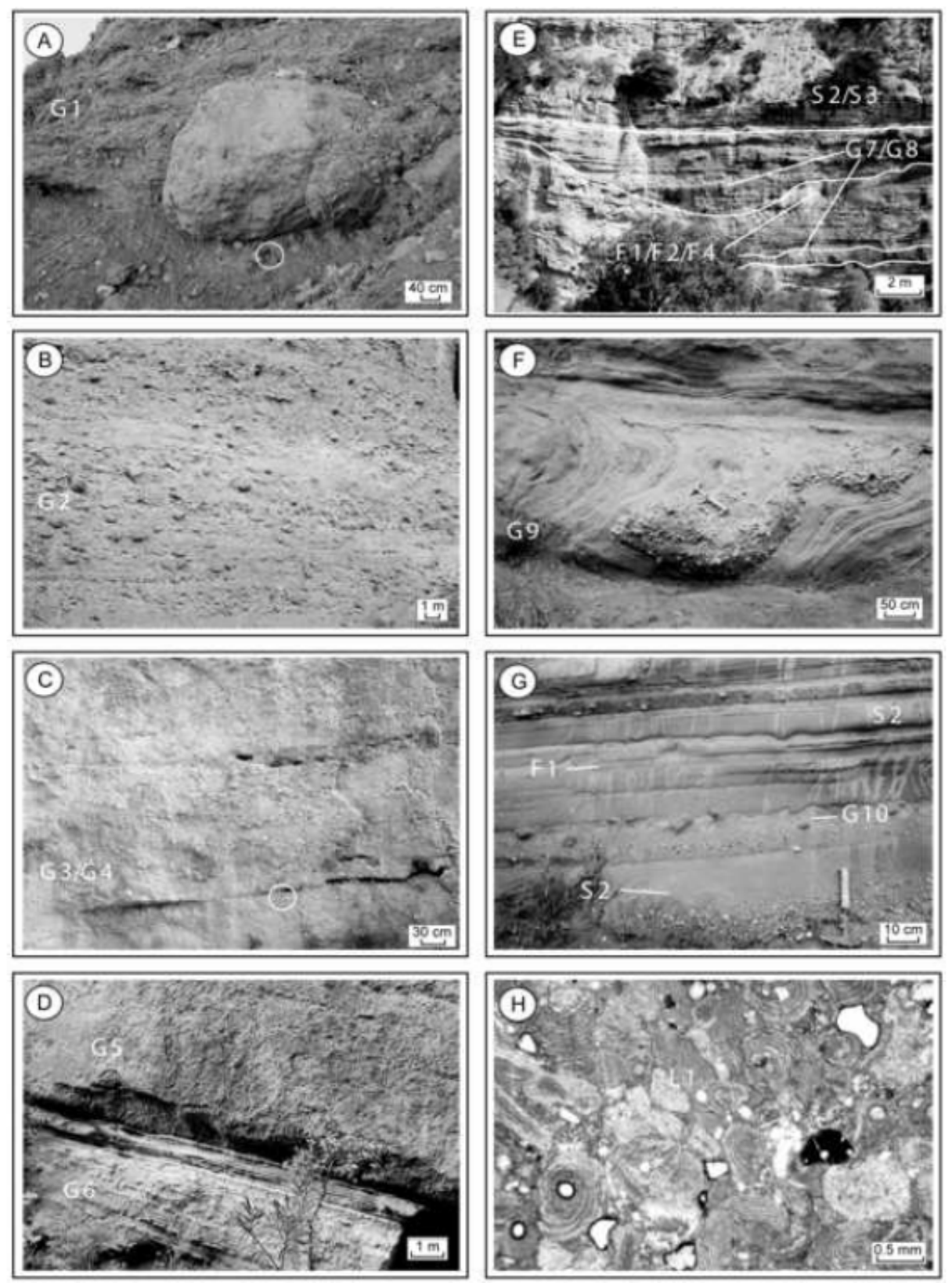
Figure 4

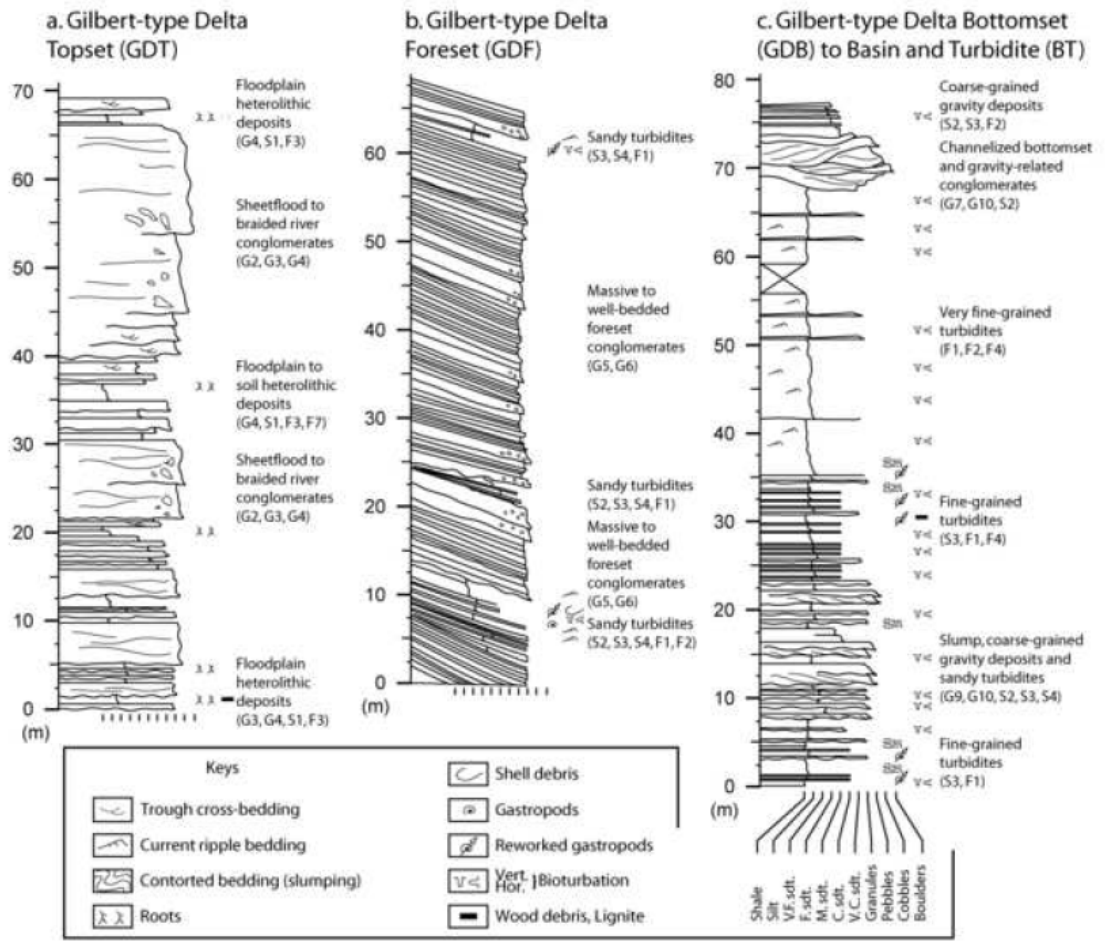


Figure 5
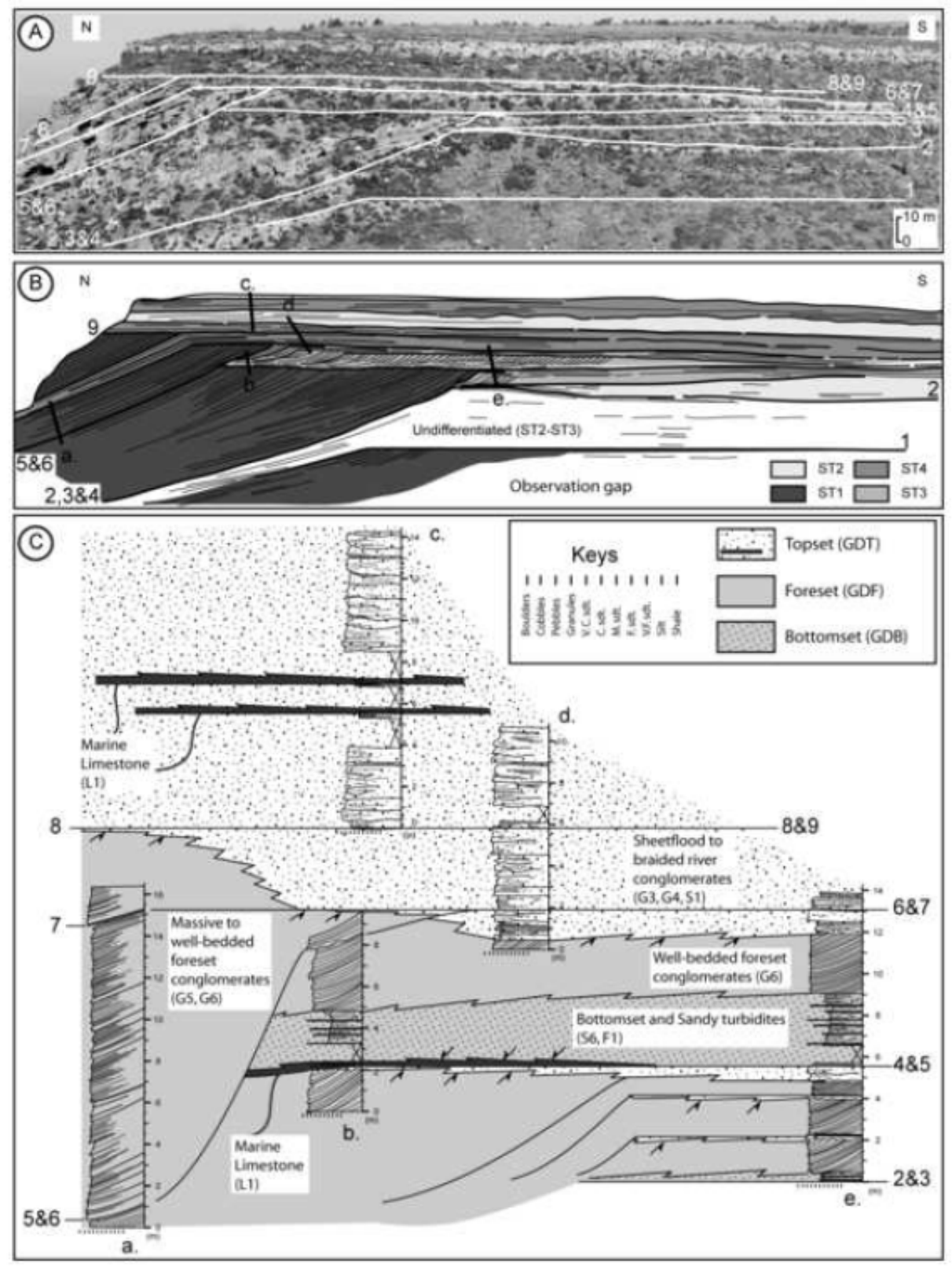

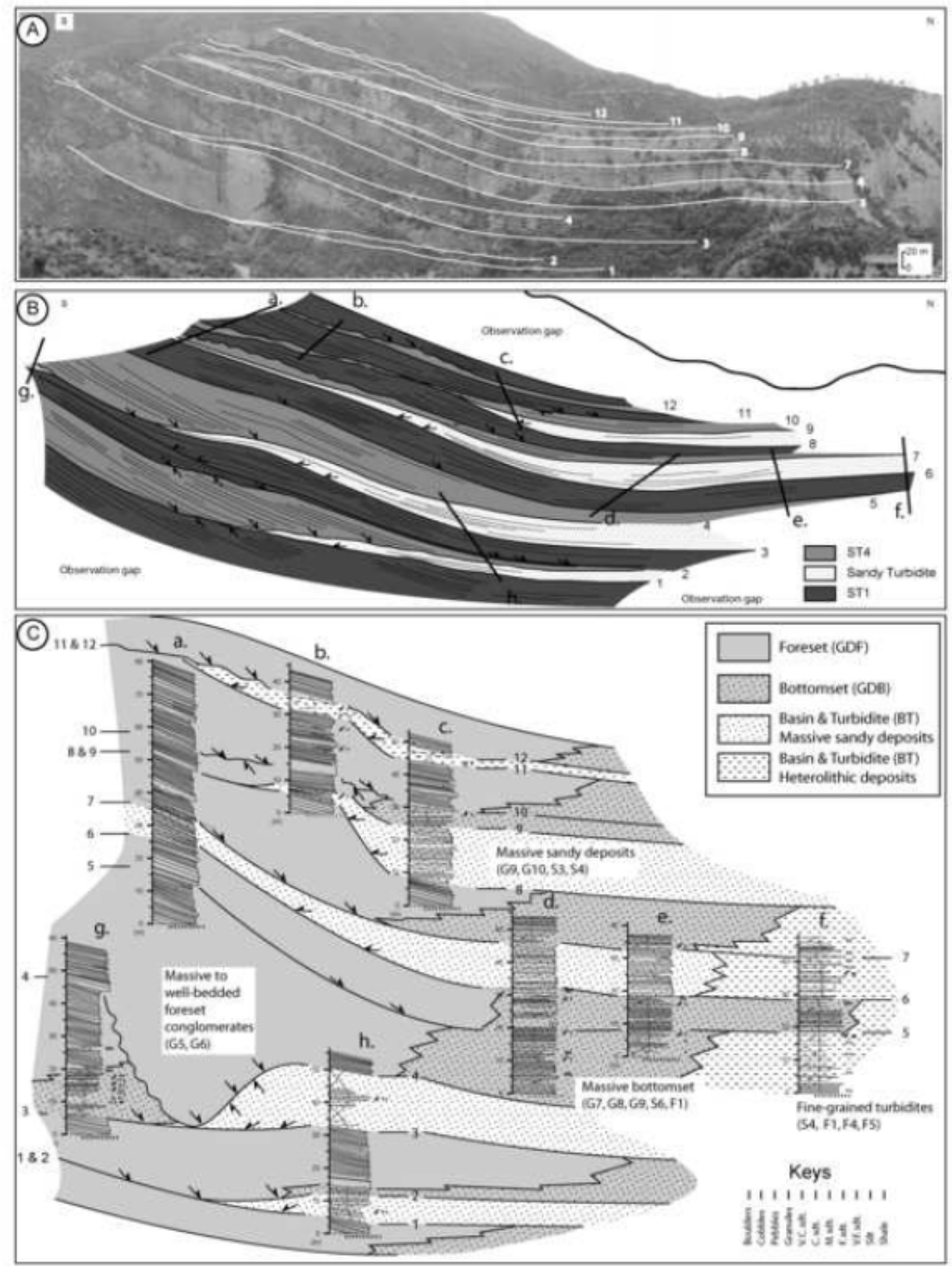

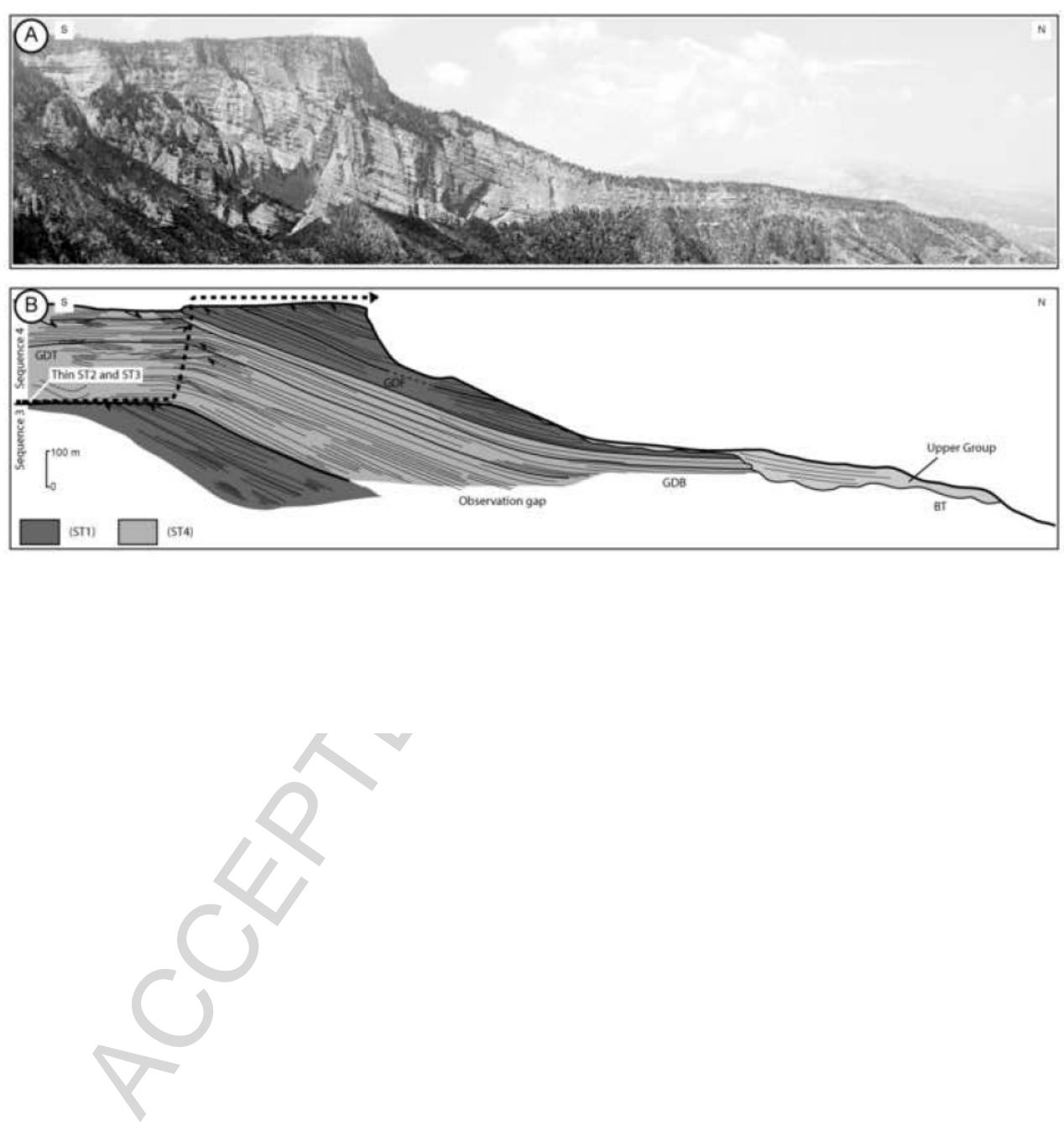


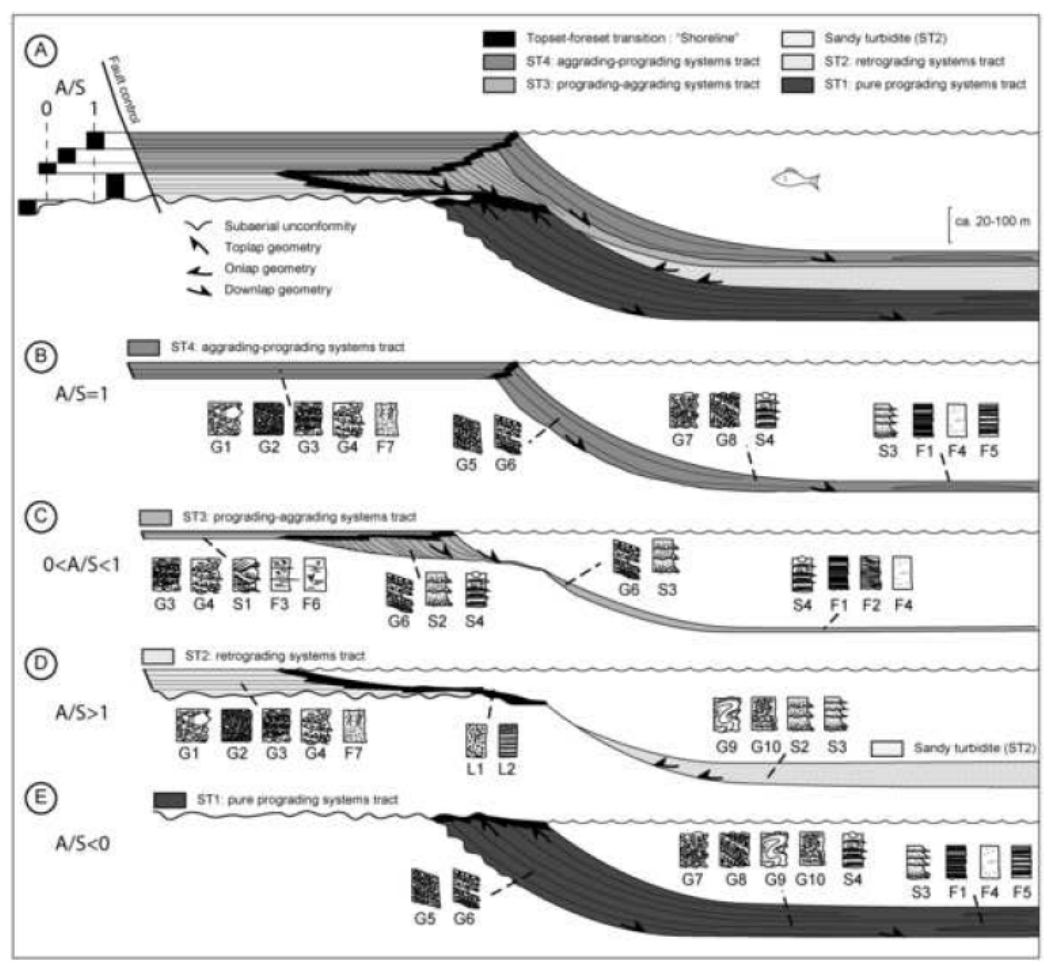




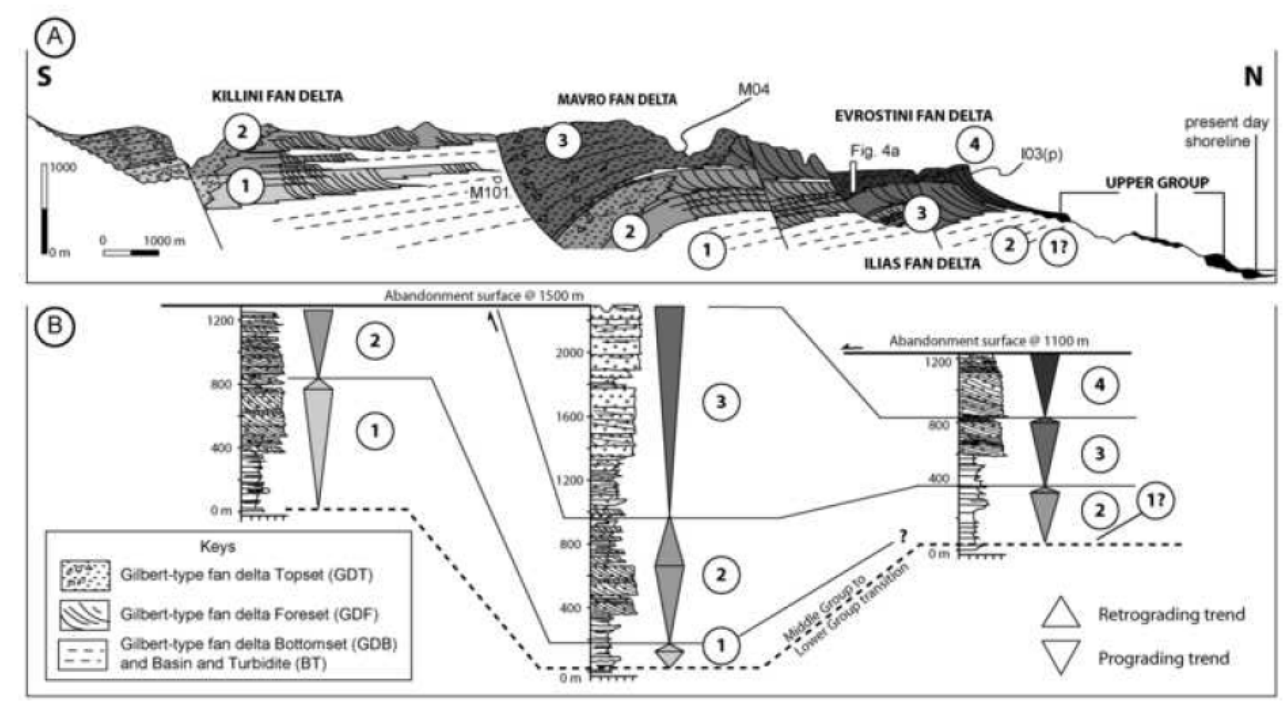


Table 1

\begin{tabular}{|c|c|c|c|c|}
\hline Facies & & Description & Bed geometry & Interpretation \\
\hline $\begin{array}{l}\text { G1: angular } \\
\text { poorly sorted } \\
\text { conglomerate }\end{array}$ & & $\begin{array}{l}\text { poorly sorted pebble-boulder conglomerate, clast- } \\
\text { supported, subangular clast and boulder ( }>1 \mathrm{~m} \text { in } \\
\text { diameter), massive to partly crudely stratified }\end{array}$ & $\begin{array}{l}\text { thick beds (up to } 10 \mathrm{~m} \text { ), } \\
\text { sheet-like geometry }\end{array}$ & $\begin{array}{l}\text { debris-flow in a steep } \\
\text { topographic gradient }\end{array}$ \\
\hline $\begin{array}{l}\text { G2: massive to tabular } \\
\text { unchannelised } \\
\text { conglomerate }\end{array}$ & & $\begin{array}{l}\text { massive to tabular pebble-boulder conglomerate, } \\
\text { clast-supported, basal inverse grading, pebbles } \\
\text { often imbricated, rare oblique cross-bedding }\end{array}$ & $\begin{array}{l}\text { thick beds (up to } 10 \mathrm{~m} \text { ), } \\
\text { amalgamated in very } \\
\text { thick units, sheet-like } \\
\text { geometry }\end{array}$ & $\begin{array}{l}\text { sheetflood deposit and } \\
\text { bedload sedimentation } \\
\text { in a steep topographic } \\
\text { gradient }\end{array}$ \\
\hline $\begin{array}{l}\text { G3: massive to tabular } \\
\text { channelised } \\
\text { conglomerate }\end{array}$ & & $\begin{array}{l}\text { very poorly sorted pebble-boulder conglomerates, } \\
\text { clast-supported, occasional tabular cross-bedding }\end{array}$ & $\begin{array}{l}\text { form thick channelised } \\
\text { units ( } 1 \text { to } 10 \mathrm{~m} \text { ). } \\
\text { laterally continuous }\end{array}$ & $\begin{array}{l}\text { bedload transport in } \\
\text { the fluvial channels, } \\
\text { high-energy systems }\end{array}$ \\
\hline $\begin{array}{l}\text { G4: tabular channelised } \\
\text { cross-stratified } \\
\text { conglomerate }\end{array}$ & & $\begin{array}{l}\text { cross-stratified pebble-cobble conglomerates, clast- } \\
\text { supported, ungraded or rarely normal grading. } \\
\text { erosional basal surface, clast imbrication }\end{array}$ & $\begin{array}{l}\text { medium to thick beds } \\
(0.5 \text { to } 5 \mathrm{~m})\end{array}$ & $\begin{array}{l}\text { bedload transport } \\
\text { mecanism, high-energy } \\
\text { systems }\end{array}$ \\
\hline $\begin{array}{l}\text { G5: steeply dipping } \\
\text { massive conglomerate }\end{array}$ & & $\begin{array}{l}\text { crudely stratified pebble-cobble conglomerate, clast- } \\
\text { to matrix-supported, clast oriented parallel to } \\
\text { stratification, erosional lower boundary }\end{array}$ & $\begin{array}{l}\text { steeply dipping }\left(25-35^{\circ}\right) \text {, } \\
\text { thick and massive } \\
\text { bedded (up to } 10 \mathrm{~m} \text { ) }\end{array}$ & $\begin{array}{l}\text { debris-flow, gravity } \\
\text { processes (foreset) }\end{array}$ \\
\hline $\begin{array}{l}\text { G6: steeply dipping well- } \\
\text { bedded conglomerate } \\
\text { (heterolithic) }\end{array}$ & & $\begin{array}{l}\text { well-bedded pebble-cobble conglomerate, clast- to } \\
\text { matrix-supported, occasionally openworked } \\
\text { framework, inverse-to-normal, inverse grading or } \\
\text { normal grading }\end{array}$ & $\begin{array}{l}\text { steeply dipping tabular- } \\
\text { bedded }\left(25-35^{\circ}\right) \text {, } \\
\text { channelized erosional } \\
\text { bases (lenses } \times 100 \mathrm{~m} \text { ) }\end{array}$ & $\begin{array}{l}\text { debris-flow, high } \\
\text { density turbidity } \\
\text { currents, } \\
\text { gravity processes } \\
\text { (foreset) }\end{array}$ \\
\hline $\begin{array}{l}\text { G7: massive } \\
\text { conglomerate } \\
\text { lenses }(\times 100 \mathrm{~m})\end{array}$ & & $\begin{array}{l}\text { massive cobble-pebble conglomerate, clast- } \\
\text { supported, inverse-to-normal and inverse grading, } \\
\text { larger clasts floating at the top of beds, erosional } \\
\text { lower and upper boundaries }\end{array}$ & $\begin{array}{l}\text { medium to thick tabular } \\
\text { bedded }(0.2 \text { to } 2 \mathrm{~m}) \text {, } \\
\text { grades basinward to } \\
\text { finer deposits }\end{array}$ & $\begin{array}{l}\text { debris-flow, gravity } \\
\text { processes }\end{array}$ \\
\hline $\begin{array}{l}\text { G8: cross-stratified } \\
\text { conglomerate lenses } \\
(\times 100 \mathrm{~m})\end{array}$ & & $\begin{array}{l}\text { cross-stratified pebble-cobble conglomerates, clast- } \\
\text { supported, ungraded or rarely inverse-to-normal and } \\
\text { inverse grading, erosional lower and upper } \\
\text { boundaries, clast imbrication }\end{array}$ & $\begin{array}{l}\text { medium to thick lenses } \\
\text { bedded }(0.2 \text { to } 2 \mathrm{~m})\end{array}$ & $\begin{array}{l}\text { bedload traction carpet } \\
\text { of high-energy gravity } \\
\text { deposits }\end{array}$ \\
\hline G9: chaotic deposit & & $\begin{array}{l}\text { chaotic deposits of folded and brecciated blocks of } \\
\text { sediment }\end{array}$ & $\begin{array}{l}\text { medium to very thick } \\
\text { bedded }(1 \text { to } 10 \mathrm{~m}) \text {. } \\
\text { restricted lateral } \\
\text { continuity }(x 10 \mathrm{~m})\end{array}$ & slumps and slides \\
\hline $\begin{array}{l}\text { G10: muddy matrix-rich } \\
\text { conglomerate }\end{array}$ & 舆 & $\begin{array}{l}\text { clast- to matrix-supported mud-clast conglomerate, } \\
\text { erosional lower and uneven upper boundaries }\end{array}$ & $\begin{array}{l}\text { thin to medium thick } \\
\text { bedded }(0.1 \text { to } 1 \mathrm{~m}) \text {. } \\
\text { restricted lateral } \\
\text { continuity }(x 10 \mathrm{~m})\end{array}$ & $\begin{array}{l}\text { cohesive debris-flow, } \\
\text { lag }\end{array}$ \\
\hline
\end{tabular}




\begin{tabular}{|c|c|c|c|c|}
\hline Facies & & Description & Bed geometry & Interprotation \\
\hline $\begin{array}{l}\text { S1: cross-strattied } \\
\text { channelised gravelly } \\
\text { sandstone (heterolithic) }\end{array}$ & & $\begin{array}{l}\text { poorty sonted sand and granule, trough cross-and } \\
\text { tabular-bedding }\end{array}$ & $\begin{array}{l}\text { form thick channelized } \\
\text { units }(0.5 \text { to } 5 \text { m), } \\
\text { laterally continuous }\end{array}$ & $\begin{array}{l}\text { bedload transport } \\
\text { mecanism, braided- } \\
\text { iver channels }\end{array}$ \\
\hline $\begin{array}{l}\text { \$2: alternation of } \\
\text { graded gravelly } \\
\text { sandstone (heterolithic) }\end{array}$ & & $\begin{array}{l}\text { graded pebbly sandstone, inverse-to-normal and } \\
\text { normal grading, sole marks (groove) }\end{array}$ & $\begin{array}{l}\text { thin to thick bedded } \\
(0.05 \text { to } 2 \mathrm{~m}) \text {, sheet } \\
\text { geometry }\end{array}$ & $\begin{array}{l}\text { surging high density } \\
\text { turbidity currents }\end{array}$ \\
\hline $\begin{array}{l}\text { S3: alternation of } \\
\text { graded sandstone } \\
\text { (heterolithic) }\end{array}$ & & $\begin{array}{l}\text { alternation of bicoloured muddy-clayey deposits and } \\
\text { fine- to coarse-grained sandstone, inverse-to-normal } \\
\text { and normal grading, horizontal and ripple lamination, } \\
\text { soft sediment deformation below erosional lower } \\
\text { boundary, scattered granules, mud clasts, coal } \\
\text { debris and shell debris in places }\end{array}$ & $\begin{array}{l}\text { medium to thick bedded } \\
\text { ( } 0.01 \text { to } 2 \mathrm{~m}) \text {, sheet } \\
\text { geometry } \\
\text { (amaigamabion), grades } \\
\text { basinward to fine } \\
\text { grained deposits }\end{array}$ & $\begin{array}{l}\text { rapid deposition from } \\
\text { surging high density } \\
\text { current, by-pass } \\
\text { previously to } \\
\text { suspension setlling } \\
\text { turbidity currents } \\
\text { (bottomset) }\end{array}$ \\
\hline $\begin{array}{l}\text { S4: wel-bedded } \\
\text { sandstone with floating } \\
\text { pebble (heterclithic) }\end{array}$ & 팔 & $\begin{array}{l}\text { claystone-sandstone, normal grading. floating } \\
\text { pebble within and at the top of beds }\end{array}$ & $\begin{array}{l}\text { thin to thick parallet } \\
\text { bedded }(0.01 \text { to } 1 \mathrm{~m})\end{array}$ & $\begin{array}{l}\text { cohesive debris-flow } \\
\text { andlor surging high } \\
\text { density } \\
\text { turbidity currents } \\
\text { (bottomset) }\end{array}$ \\
\hline $\begin{array}{l}\text { F1: laminated muddy } \\
\text { sandstone } \\
\text { (heterolithic) }\end{array}$ & & $\begin{array}{l}\text { thin to thick paraliof-bedided claystone-sandstone } \\
\text { multiple couplets (mudstone prevaling). current } \\
\text { ripple, normal grading developed above erosional } \\
\text { lower boundary }\end{array}$ & $\begin{array}{l}\text { thin to thick parallet- } \\
\text { bedded }(0.01 \text { to } 0.1 \mathrm{~m})\end{array}$ & $\begin{array}{l}\text { traction to suspension } \\
\text { currents from low- } \\
\text { concentration turbidity } \\
\text { currents }\end{array}$ \\
\hline $\begin{array}{l}\text { F2: undulated muddy } \\
\text { siltstone (heterolithic) }\end{array}$ & & $\begin{array}{l}\text { cross- to paralle-Haminated silty-clayey deposits, } \\
\text { ripple-marks and sole marks, erosional upper and } \\
\text { lower boundaries }\end{array}$ & $\begin{array}{l}\text { variably bedded ( } 0.01 \text { to } \\
0.5 \mathrm{~m} \text { ), high amplitude } \\
\text { undulatory bedding ( } 5 \text {. } \\
30 \mathrm{~m} \text { ) }\end{array}$ & $\begin{array}{l}\text { weak to low- } \\
\text { concentration traction } \\
\text { currents from diluted } \\
\text { turbidity currents }\end{array}$ \\
\hline $\begin{array}{l}\text { F3. well-bedded to } \\
\text { massive mudistone } \\
\text { (helerolithic) }\end{array}$ & & $\begin{array}{l}\text { thick homogeneous mudstone-claystone thinly } \\
\text { interbedded with claystones, siltstones and } \\
\text { sandstones, planar to low-angle laminations, ripple- } \\
\text { marks, pedogenetic alteration (rootiets), plant debris } \\
\text { and lignite fragments }\end{array}$ & $\begin{array}{l}\text { massive to thin } \\
\text { parallel-bedded }(0.01 \\
\text { to } 5 \mathrm{~m})\end{array}$ & $\begin{array}{l}\text { suspension settling on } \\
\text { floodplain, fluvial levee, } \\
\text { subaqeous overbank } \\
\text { deposits of } \\
\text { interdistributary } \\
\text { channels }\end{array}$ \\
\hline $\begin{array}{l}\text { F4. massive muddy } \\
\text { siltstone }\end{array}$ & & $\begin{array}{l}\text { massive to planar-laminated micritic claystone- } \\
\text { siltsone (white), rarely bioturbated }\end{array}$ & $\begin{array}{l}\text { thin to thick parallel- } \\
\text { bedded }(0.1 \text { to } 1 \mathrm{~m})\end{array}$ & $\begin{array}{l}\text { dilute uniform } \\
\text { suspension or rapid } \\
\text { deposition due to } \\
\text { ponding of fine-grained } \\
\text { turbidity currents }\end{array}$ \\
\hline F5: varved claystone & & $\begin{array}{l}\text { claystone-siltstone contains plant debris and/or } \\
\text { freshwater fauna }\end{array}$ & $\begin{array}{l}\text { thinly parallel-bedded } \\
\text { (varves) }(0.01 \text { to } 0.05)\end{array}$ & $\begin{array}{l}\text { lake floor suspension } \\
\text { deposits }\end{array}$ \\
\hline $\begin{array}{l}\text { F6. well-bedded } \\
\text { bioturbated } \\
\text { mudstone }\end{array}$ & 3 & $\begin{array}{l}\text { mudstone-siltstone contains plant debris and/or } \\
\text { freshwater to brackish fauna, bioturbation, thin to } \\
\text { thick lignite accumulation, well-preserved plant. } \\
\text { wood bark, sulphur or gypwum, layered pedogenic } \\
\text { features }\end{array}$ & $\begin{array}{l}\text { thin parallel-bedded } \\
(0.01 \text { to } 0.2 \mathrm{~m})\end{array}$ & $\begin{array}{l}\text { backswamp to } \\
\text { lagoonal deposit, lake } \\
\text { floor suspension } \\
\text { deposits }\end{array}$ \\
\hline F7: reddish claystone & & $\begin{array}{l}\text { burrowed and rooted reddish mudstone-claystone, } \\
\text { pedogenic horizon, humic accumulation (lignite). } \\
\text { carbonate concretion }\end{array}$ & & soil \\
\hline $\begin{array}{l}\text { L1: algal bioclastic } \\
\text { limestone }\end{array}$ & 202 & $\begin{array}{l}\text { massive to difluse-laminated grainstone, ripple- } \\
\text { marks, shell debris, red algal, green algal, blue } \\
\text { algail }\end{array}$ & $\begin{array}{l}\text { thin to thick bedded or } \\
\text { lenses }\end{array}$ & $\begin{array}{l}\text { back barner, bay, } \\
\text { marine environment }\end{array}$ \\
\hline 1.2. laminated limestone & & $\begin{array}{l}\text { diffuse- to planar-taminated limestone contains plant } \\
\text { debris andior freshwater to brackiah fauna }\end{array}$ & $\begin{array}{l}\text { thin parallei-bedded } \\
(0.01 \text { to } 0.1 \mathrm{~m}) \text {, laterally } \\
\text { continuous }\end{array}$ & $\begin{array}{l}\text { lake to backswamp } \\
\text { suspension deposits }\end{array}$ \\
\hline
\end{tabular}

